\title{
PERANAN PEMBELAJARAN SEJARAH DALAM PENANAMAN NILAI KARAKTER NASIONALISME
}

\author{
Elisa Dewi Juliyati \\ Email: 1810111220013@mhs.ulm.ac.id \\ Program Studi Pendidikan Sejarah Fakultas Keguruan dan Ilmu Pendidikan \\ Universitas Lambung Mangkurat \\ Banjarmasin
}

\begin{abstract}
Abstrak
Penanaman nilai-nilai nasionalisme dalam pembelajaran sejarah merupakan hal yang sangat penting diterapkan di era globalisasi ini. Penanaman nilai nasionalisme dapat menjadi contoh untuk membentuk karakter bangsa yang sesuia dengan identitas bangsa. Pendidikan karakter merupakan upaya yang dilakukan oleh pihak sekolah untuk membentuk, mengarahkan dan membimbing perilaku peserta didik yang sesuai dengan nilai-nilai yang bersumber pada norma-norma tertentu untuk mengatasi dampak negative dari era globalisasi. Salah satu dampak negatif yang ditimbulkan adalah minat generasi muda terhadap kebudayaan sendiri mulai memudar dan mengakibatkan bergesernya nilai dalam kehidupan baik pribadi maupun bermasyarakat. Pengaruh pendidikan sejarah terhadap sikap nasionalisme pada peserta didik terdapat pengaruh yang signifikan dan positif dari pendidikan sejarah terhadap sikap nasionalisme peserta didik. Hal ini berarti sikap nasionalisme dapat dijelaskan dan dipengaruhi oleh pendidikan sejarah, pembelajaran sejarah memberikan materi-materi tentang nilai-nilai nasionalisme sehingga siswa mampu memahami nilai tersebut, ini menunjukkan besarnya peran pendidikan sejarah terhadap pembentukkan sikap nasionalisme di kalangan peserta didik.
\end{abstract}

\section{PENDAHULUAN}

Pendidikan merupakan suatu sistem yang teratur dan mengemban misi yang cukup luas yaitu segala sesuatu yang berkaitan dengan perkembangan fisik, kesehatan, keterampilan, pikiran, perasaan, kemauan, sosial sampai kepada masalah kepercayaan atau keimanan. Hal ini menunjukkan bahwa sekolah sebagai suatu lembaga pendidikan formal mempunyai suatu muatan beban yang cukup berat dalam melaksanakan misi pendidikan tersebut. Lebih-lebih kalau dikaitkan dengan pesatnya perubahan zaman dewasa ini yang sangat berpengaruh terhadap anak-anak didik dalam berfikir, bersikap dan berperilaku, 
khususnya terhadap mereka yang masih dalam tahap perkembangan dalam transisi yang mencari identitas diri.

Derasnya arus globalisasi, membawa pengaruh bagi kehidupan suatu negara, ternyata berpengaruh juga dengan nilai-nilai nasionalisme Indonesia dan mempengaruhi mutu pendidikan. Generasi muda sebagai generasi penerus bangsa harusnya memiliki tanggung jawab dalam usaha membina dan melestarikan nasionalisme, sebab nasionalisme telah menjadi jembatan emas bagi para pahlawan untuk memproklamirkan kemerdekaan ini. Tanpa adanya pembinaan Nasionalisme terhadap generasi muda kita khawatir, bangsa ini terjerumus dalam kolonialisme baru sesuai dengan jamannya. Berbagai pengaruh luar yang masuk dengan adanya globalisasi tentu akan mendatangkan sebuah tantangan baru dalam tatanan kehidupan berbangsa dan bernegara. Berkaitan dengan fenomena pengaruh dari globalisasi yang sangat mengkhawatirkan masyarakat terlebih pada generasi muda, pemerintah mengeluarkan kebijakan mengenai pendidikan, dengan menanamkan nilai-nilai karakter khususnya dalam mata pelajaran sejarah memberikan arti yang strategis dalam pembentukan watak dan peradaban bangsa yang bermatabat serta memiliki rasa kebangsaan dan cinta tanah air. Salah satu upaya dalam pembentukan watak dan peradaban bangsa yaitu dengan pembelajaran sejarah.

Dalam masa pembangunan dewasa ini, salah satu fungsi pendidikan adalah mengembangkan kesadaran nasional sebagai daya mental dalam proses pembangunan nasional dan identitasnya. Struktur kepribadian nasional tersusun dari karakteristik perwatakan yang tumbuh dan melembaga dalam proses pengalaman sepanjang kehidupan bangsa. Dengan demikian kepribadian dan identitasnya bertumpu pada pengalaman kolektif, yaitu pada sejarahnya. Dalam konteks pembentukan identitas bangsa, maka pendidikan sejarah mempunyai fungsi yang fundamental (Kartodirdjo S. , 1999:45)

Perkembangan selanjutnya dalam pendidikan sejarah terjadi pergeseran dari perenialisme ke esensialisme bahkan rekontruksionisme sosial bergabung secara ekletik (Hasan, 1999:9). Pendidikan sejarah tidak saja menjadi wahana memahami keagungan masa lampau dan pengembangan kemampuan intelektual ataupun center for excellence, tetapi juga menjadi wahana dalam upaya memperbaiki kehidupan sosial, budaya, politik, dan ekonomi.

\section{PEMBELAJARAN SEJARAH DAN PENDIDIKAN KARAKTER}

Pembelajaran sejarah merupakan cabang ilmu pengetahuan yang menelaah tentang asal-usul dan perkembangan serta penanan maasyarakat pada masa lampau yang mengandung nilai-nilai kearifan yang dapat digunakan untuk melatih kecerdasan, membentuk sikap, watak dan kepribadian peserta didik (Sapriya, 2012:209-210). Pembelajaran sejarah berfungsi untuk menyadarkan peserta didik akan adanya proses perubahan dan perkembangan masyarakat dalam dimensi waktu dan untuk membangun perspektif serta kesadaran sejarah dalam menemukan, memahami, dan menjelaskan jati diri 
bangsa di masa lalu, masa kini, dan masa depan di tengah-tengah perubahan dunia (Depdiknas, 2003:6). Pembelajaran sejarah juga merupakan cara untuk membentuk sikap sosial. Adapun sikap sosial tersebut antara lain: saling menghormati, menghargai perbedaan, toleransi dan kesediaan untuk hidup berdampingan dalam nuansa multikulturalisme (Susanto, 2014:62).

Pembelajaran sejarah memiliki peran yang sangat penting di dalam pembentukan watak, sikap dan perkembangan bangsa yang bermakna dalam pembentukan bangsa Indonesia yang memiliki rasa kebangsaan, intelektual, menghargai perjuangan bangsanya dan rasa nasionalisme. Sumber sejarah berasal dari jejak atau kesaksian yang ditinggalkan dalam peristiwa, Kemudian ditafsirkan oleh sejarawan sehingga dapat menceritakan tentang realitas masa lalu. Dalam konteks ini termasuk tradisi lisan yang menjadi memori kolektif masyarakat yang dapat dijadikan sumber sejarah yang digunakan oleh sejarawan. Awalnya tradisi lisan banyak ditolak oleh sebagian sejarawan sebagai sumber sejarah karena dianggap historis. (Anis, 2015:57). Peran penting pembelajaran sejarah bukan hanya sebagai proses transfer ide, akan tetapi juga proses pendewasaan peserta didik untuk memahami identitas, jati diri dan kepribadian bangsa melalui pemahaman terhadap peristiwa sejarah.

Pendidikan karakter merupakan proses untuk menuntun peserta didik menjadi manusia seutuhnya yang berkarakter dalam hati, raga, pikir, serta rasa dan karsa. Pendidikan karakter dapat dimaknai sebagai pendidikan nilai, pendidikan budi pekerti, pendidikan moral, pendidikan watak, yang bertujuan mengembangkan kemampuan peserta didik untuk memberikan keputusan baik buruk, memelihara apa yang baik, dan mewujudkan kebaikan itu dalam kehidupan sehari-hari dengan sepenuh hati (Samani, 2011:45). Pendidikan karakter bertujuan untuk meningkatkan mutu penyelenggaraan dan hasil pendidikan di sekolah yang mengarah pada pencapaian pembentukan karakter dan akhlak mulia peserta didik secara utuh, terpadu dan seimbang, sesuai standar kompetensi lulusan. Melalui pendidikan karakter diharapkan peserta didik mampu secara mandiri meningkatkan dan menggunakan pengetahuannya untuk mengkaji, menanamkan, serta memaknai nilai-nilai karakter dan akhlak mulia sehingga terwujud dalam perilaku seharihari (Amri 2011:31).

Hubungan antara pendidikan sejarah dengan pendidikan karakter ialah tujuan belajar sejarah yang nation and character building. Karakter nama lain dari personality, Watak atau jati diri. Karakter individu menjadi kajian para psikolog, sedangkan karakter sebuah bangsa menjadi kajian antropologi (Anis, 2014: 484). Pendidikan karakter di sekolah akan terlaksana dengan lancar, jika pendidik dalam pelaksanaanya memperhatikan prinsip pendidikan karakter. Prinsip pengembangan karakter mengusahakan agar peserta didik mengenal dan menerima nilai-nilai karakter sebagai milik peserta didik dan bertanggung jawab atas keputusan yang diambil melalui tahapan mengenal pilihan, menilai 
pilihan, menentukan pendirian dan selanjutnya menjadikan suatu nilai sesuai dengan keyikinan diri (Fathurrohman, 2013:83)

\section{NILAI KARAKTER NASIONALISME PEMBELAJARAN SEJARAH}

Salah satu nilai karakter dalam pembelajaran sejarah bermuatan nilai nasionalisme, Pendidikan sejarah diharapkan dapat mensosialisasikan dan menginternalisasikan nilai-nilai tersebut, sehingga peserta didik mempunyai kesadaran sejarah dan kepribadian bangsa. Nation adalah jiwa dan semangat yang membentuk sebuah ikatan bersama, baik dalam hal kebersamaan maupun dalam hal pengorbanan. Menurut Kartodirdjo (1972:64) bahwa nasionalisme sebagai fenomena historis, timbul sebagai jawaban terhadap kondisi-kondisi historis, politik ekonomi dan sosial tertentu. Kondisi-kondisi yang dimaksudkan adalah munculnya kolonialisme dari suatu negara terhadap negara lainnya. Hal ini terjadi sebab nasionalisme itu sendiri muncul sebagai suatu reaksi terhadap kolonialisme, reaksi yang berasal dari sistem eksploitasi yang selalu menimbulkan pertentangan kepentingan secara terus menerus.

Pendidikan sejarah dengan sikap nasionalisme menunjukkan terdapat hubungan yang signifikan serta pengaruh yang kuat dalam pengertian pendidikan sejarah yang menarik akan membentuk sikap nasionalisme. Pendidikan sejarah yang menyenangkan akan mengubah paradigma peserta didik tentang sejarah itu sendiri. Model pengajaran yang tepat untuk pendidikan sejarah akan menambah semangat peserta didik untuk menggali segala potensi bangsa dan negara sehingga muncul kebanggaan terhadap bangsanya sendiri. Belajar sejarah dapat mengkonsepsikan kehidupan sesuai dengan perjalanan waktu yang terjadi dengan menempatkan diri kita di dalamnya. Menanamkan rasa bangga terhadap pendidikan sejarah bukanlah hal yang mudah, diperlukan berbagai upaya untuk membuat pendidikan sejarah disukai oleh peserta didik.

Peran pendidikan sejarah terhadap pembentukan sikap nasionalisme di kalangan peserta didik memiliki hubungan dengan sikap nasionalisme yang begitu besar. Sejarah memang telah merekam peristiwa-peristiwa yang mampu melahirkan emosi, sikap, nilai, cita-cita yang memberikan hidup bermakna melalui sebuah perjuangan hidup yang membutuhkan pengorbanan diri bahkan bertaruh dengan nyawa. Sejarah juga dapat memunculkan segala kesetiaan seseorang kepada negara, agama maupun kelompoknya sendiri.

Proses penanaman nilai-nilai nasionalisme dilakukan oleh guru dengan berbagai cara. Nilai-nilai yang ditanamkan pada peserta didik pada saat pembelajaran berlangsung seperti misalnya materi proklamasi kemerdekaan adalah seperti cinta tanah air, persatuan dan kesatuan, rela berkorban, berani dan disiplin. Nilai selanjutnya adalah persatuan dan kesatuan. Nilai tersebut penting ditanamkan kepada peserta didik karena diketahui pada era saat ini terdapat tawuran yang dilakukan oleh antar pelajar. Nilai persatuan yang terdapat pada materi tersebut adalah menyatunya segala suku bangsa dari berbagai daerah demi 
kemerdekaan Indonesia. Guru sejarah mengaplikasikan nilai persatuan dan kesatuan tersebut di dalam kelas pada saat pembelajaran yaitu dengan saling menghargai pada saat terdapat teman yang bertanya. Tidak mencela pendapat teman serta menghargai sesame sehingga tidak menimbulkan perpecahan. Peserta didikpun sudah ada beberapa yang menerapkan nilai nasionalisme persatuan dan kesatuan tersebut dengan tidak memaksakan pendapat pribadi apabila terdapat pendapat teman yang berbeda dengan pendapat pribadi mereka.

Selain pembelajaran sejarah, penanaman nilai-nilai nasionalisme juga dilakukan melalui peraturan sekolah. Peraturan sekolah dalam rangka penanaman nilai-nilai nasionalisme siswa sudah dikembangkan dan dilaksanakan dengan baik, Penegakan pelanggaran peraturan juga sudah diberlakukan sehingga akan lebih mendukung upaya penanaman nilai-nilai nasionalisme. Peraturan sekolah pada intinya akan memberikan dukungan dan identitas terhadap sekolah.

\section{SIMPULAN}

Dengan pendidikan sejarah diharapkan akan timbul kesadaran sejarah yang diharapkan dapat membantu peserta didik mengenal dirinya dalam hidup bersama di komunitas yang lebih besar, sehingga menumbuhkan kesadaran kolektif dalam memiliki kebersamaan dalam sejarah, kebersamaan dalam memiliki riwayat masa lampau. Proses pengenalan diri yang meningkat menjadi kesadaran kolektif ini merupakan titik awal timbulnya rasa harga diri, rasa bangga dan rasa memiliki terhadap bangsa dan tanah air. Proses penanaman nilai nasionalisme dilakukan dengan menanamkan beberapa nilai nasionalisme. Nilai yang ditanamkan guru pada saat pembelajaran sejarah tersebut di antaranya adalah: rasa cinta tanah air, persatuan dan kesatuan, rela berkorban, disiplin, dan berani.

\section{REFERENSI}

Anis, M. Z. A., \& Mardiani, H. S. S. F. (2021). Analysis of the Effectiveness of MPBH: The Mains of Mandai as a Saving Food in Banjarmasin Community.

Anis, M. Z. A., Putro, H. P. N., Susanto, H., \& Hastuti, K. P. (2020). Historical Thinking Model in Achieving Cognitive Dimension of Indonesian History Learning. PalArch's Journal of Archaeology of Egypt/Egyptology, 17(7), 7894-7906.

Anis, M. Z. A \& Susanto, H. (2015). Sejarah Bukan Warisan Melainkan Pembelajaran. Prosiding dari Seminar Nasional Asosiasi dan Pendidik Sejarah dengan Tema Pendidikan Sejarah Untuk Menyiapkan Generasi Emas Indonesia 2050: 53-64. 
Anis, M. Z. A. (2014) Sejarah, Pendidikan Sejarah, dan Pendidikan Karakter Dialog yang Tidak Pernah Dituntaskan. In: Building Nation Character Through Education: Proceeding International Seminar on Character Education.

Anis, M. Z. A. (2014). Sejarah, Pendidikan Sejarah, dan Pendidikan Karakter Dialog yang Tidak Pernah Dituntaskan. Program Studi Pendidikan Sejarah FKIP Unlam Lambung Mangkurat.

Amri, S, dkk. 2011. Implementasi Pendidikan Karakter dalam Pembelajaran: Strategi Analisis dan Pengembangan Karakter Peserta didik dalam Proses Pembelajaran. Jakarta: Prestasi Pustakaraya.

Fathurrohman, P dkk, (2013). Pengembangan Pendidikan Karakter. Bandung: Refika Aditama.

Hasan, H. S. (1999). 'Pendidikan Sejarah untuk Membangun Manusia Baru Indonesia”. Mimbar Pendidikan. Nomor 2, Tahun XVIII.

Samani, Muchlas dan Hariyanto. (2011). Konsep dan Model Pendidikan Karakter. Bandung: Remaja Rosdakarya.

Sapriya. (2009). Pendidikan IPS Konsep dan Pembelajaran. Bandung: PT Remaja Rosdakarya.

Susanto, H. (2020). PEDAGOGI SEJARAH, NASIONALISME DAN KARAKTER BANGSA.

Syaharuddin, S., \& Susanto, H. (2019). Sejarah Pendidikan Indonesia (Era Pra Kolonialisme Nusantara sampai Reformasi). Banjarmasin: FKIP Universitas Lambung Mangkurat.

Susanto, H. 2014. Seputar Pembelajaran Sejarah, Isu, Gagasan dan Strategi Pembelajaran. Yogyakarta: Aswaja Pressindo. 